1909. Mura, F.-Report on the sugar cane borer in the Moluccas. The Hawaiian Planters' Record, Aug., p. 40-48, 1 map showing routes taken by Mr. Muir.

1909. Murr, F.-Concluding report on travels in the Malay Archipelago, in search of parasites for the cane borer. The Hawaiian Planters' Record, Nov., p. 256-261.

1910. Murr, F.-Report on second trip to British New Guinea to obtain a Tachinid fly, parasitic on the sugar cane beetle borer. The Hawaiian Planters' Record, Oct., p. $186-200,5$ figs. of fly.

1911. Villeneuve, Dr. J.-Desoription of Ceromasia sphenophori. Wiener Entomologische Zeitung, Vol. XXX, p. 81.

\title{
A NOTE ON RHAGOLETIS POMONELLA IN BLUEBERRIES'
}

By William C. Woods

In the spring of 1913 the attention of the Maine Agricultural Experiment Station was called to a certain maggot infesting the blueberries in Washington County; and, accordingly, at the suggestion of Dr. Edith M. Patch, the writer made a few observations on this insect during the summer. Although the work was merely of a preliminary character, the adult was reared, and it seems possible that a brief statement of the situation may be of interest. When bred, the maggot proved to be Rhagoletis pomonella Walsh. This appears to be the first record from the blueberry, although at least twice it has been reported as bred from the huckleberry, once by Doctor Britton in 1906 (Fifth Report State Entomologist of Connecticut, 1905, p. 260), and again in 1910 by Doctor Smith (Report New Jersey State Museum for 1909 , p. 802).

Washington County, which includes a considerable territory in southeastern Maine, is the principal home of the blueberry industry in the state. Roughly speaking, there is a large area of about 250,000 acres in this county naturally unforested, known as the "barrens," which has grown up almost entirely with blueberries. Three of the species, Vaccinium pennsylvanicum, V. canadense, and $V$. vacillans, were to be found attacked by the maggot during 1913. The plains are privately owned, but during the berry season, for a moderate rental, pickers are granted the right to gather the berries, most of which are sold to one or another of the eleven canneries located in the state.

July 30 , when the berries were just beginning to ripen, was the first date on which the plains were visited. No maggots were in evidence, but six adult Trypetids were caught hovering around the berries. These flies resembled the apple maggot exactly, except that

'Papers from the Maine Agricultural Experiment Station: Entomology No. 73. 
they were smaller. Specimens were submitted to Mr. C. W. Johnson of Boston, who very kindly determined them as undoubteddy Rhagoletis pomonella. It is interesting to note in this connection that the flies reared from huckleberries in Connecticut were also below the normal size of the apple forms.

On August 19, when the plains were again visited, six more adults were taken. Larvæ were by this time common on the plains. When the maggots are small, an infested berry cannot be distinguished by sight from a sound one, but usually when they have attained a fair size the fruit becomes very much shrivelled and shrunken. At all times, even when the larvæ are small, an infested berry can easily be distinguished by the touch, for it feels soft and mushy, and this is the surest external indication that it has been attacked. In an infested berry, the pulp becomes red and stringy. Maggots were found at this time in all stages from very small ones to those fully grown. The maggot appears to become full fed in one berry, which it leaves by an irregularly shaped exit hole through the skin, in order to pupate in the ground.

The berries are picked by a rake somewhat similar to that used for cranberries, and usually are given a preliminary winnowing in the field to remove the leaves, etc. Many of the infested berries are also blown out in this process as they are much lighter than the others. Whilc the maggots were common to abundant on the plains, it should be stated that the blueberries grew so profusely, oftentimes being so plentiful as literally to color the ground blue, that only a small proportion of the fruit was infested. The testimony of the pickers varied greatly, but the opinion of most seemed to be that the maggots became more and more numerous as the season advanced, and that a wet senson was particularly favorable to their development.

A third trip on September 5 showed the maggots still present and common in all stages.

Berries were placed under breeding cages on cheese cloth spread over moist dirt, and the larvæ that had left the berries, as well as the pupæe, were removed from these cages as follows:

\section{Material Collected July 30}

29 pupæe on August 22.

Material Collected August 19

Aug. 22 Aug. 23 Aug. 25 Aug. 27 Aug. 28 Aug. 30 Sept. 2 Sept. 4 Sept. 8

$\begin{array}{lrrrrrrrrr}\text { Pupre } & 7 & 4 & 4 & 33 & 7 & 22 & 38 & 10 & 50 \\ \text { Larve } & 4 & 6 & 20 & 3 & 7 & 2 & 7 & 2 & \end{array}$

Material Collected September 5

$\begin{array}{lcccccc} & \text { Sept. } 9 & \text { Sept. 13 } & \text { Sept. 15 } & \text { Sept. 22 } & \text { Sept. 24 } & \text { Sept. 26 } \\ \text { Pupx } & 20 & 16 & 12 & 15 & 18 & 4 \\ \text { Larva } & 9 & 14 & 26 & 5 & 1 & 4\end{array}$


On February 12, 1914, an adult male emerged in the laboratory which is the same species as those taken on the barrens last summer, thus establishing beyond a doubt the fact that at least in southeastern Maine the maggot which breeds commonly in the blueberries is Rhagoletis pomonella.

\section{INJURY TO TRUCK CROPS BY SPRING-TAILS '}

(Smynthurus sp.)

By D. E. Fink, Entomological Assistant [Truck Crap and Stored Product Insect Investigations], Bureau of Entomology, C. S. Dept. Agr.

\section{RECENT INJURY}

For the past year, 1913-14, instances of injury by spring-tails to lettuce, spinach, and seedling cucumber came under the observation of the writer in the vicinity of Norfolk, Virginia. During the springof 1913 a seedling bed of lettuce was found injured by a species of spring-tail near Mason Creek, Va. Later, seedling cucumbers just above ground were severely infested, the injury being so severe that a replanting was necessary. During the fall of 1913 spinach was infested with spring-tails but no injury was evident. Very late in autumn, a large number of the spinach plants began to turn yellow from the center outward. At this time the spring-tails were found in small numbers at the base of the plants and not on the foliage. Whether the spring-tails are concerned in the injury to spinach which is in this vicinity known as "blight" is as yet mere conjecture. But the fact that during the late fall and winter the spring-tails confine their attacks on the spinach to the petioles of the leaves would cause the latter to turn yellow and later give the observer the impression that it is due to "blight," as the leaves show no form of injury by insects.

On April 30 and May 1, 1914, seedling cucumbers were again found severely infested by spring-tails. These little pests have increased enormously since the past year and the cotyledons of cucumbers have in many instances been completely devoured as they appeared above ground. On May 2, 1914, a field of potatoes in Kempsville, Va., bearing vines only two inches above ground was found severely infested with spring-tails. They were found feeding on both the upper and lower surfaces of the leaves, as well as on the margins where the Colorado potato beetle (Leptinotarsa 10-lineata Say.) had been feeding. As many as 40 to 60 spring-tails were counted on a leaf, and several hundred to a plant. Although the spring-tails are easily disturbed, the

${ }^{3}$ Published by permission of the Secretary of Agriculture. 